\title{
EARNINGS QUALITY VERSUS ACCOUNTING REGULATION. EMPIRICAL ASSESMENT ON ACCURACY OF MACROECONOMIC ESTIMATES
}

\author{
Valentin BURCA ${ }^{a^{*}}$ \\ ${ }^{a}$ West University of Timisoara, Romania
}

DOI: $10.24818 / \mathrm{IMC} / 2020 / 01.07$

\begin{abstract}
On the light of recent economic crisis and increasing uncertainty on macroeconomic systems, public policies have to be properly defined, implemented and continuously monitored. Economic growth estimates are essential on budgetary projection, as the basis for financing all public policies. Our study consists of an empirical assessment of the impact of earnings quality on the accuracy of economic growth estimates. In order to asses isolated direct and indirect effects of earnings quality and quality of accounting regulation, we proceed to a path analysis. The main results reveal that quality of the accounting regulation is not sufficient to ensure a significant increase on earnings quality. However, perceived high quality of accounting regulation imply a positive marginal impact on the accuracy of economic growth estimates. In spite of those results, seem earnings quality determine a marginal decrease in the accuracy of economic growth.
\end{abstract}

KEYWORDS: economic growth, earnings quality, path analysis, SARS.

\section{INTRODUCTION}

Up-to-date wide range of research papers have addressed essential topics related to quality of information disclosed either by statutory financial statements, or by different other corporate financial and non-financial report, predefined through a more flexible reporting framework, as the more recent sustainability reporting, or the integrated reporting. No matter the framework used along the financial reporting supply chain, information disclosed is required to be relevant and represent faithfully financial position and financial performance of reporting entities. However, the concept of earnings quality quite ambiguous as it depends on users' objectives (Cohen et al., 2004; Dechow et al., 2010). As different groups of users of financial information have most of the time conflicting objectives, the mission to define the quality of financial statements become even more difficult (Sunder, 2016). The economics behind financial statements and accounting regulation, the role of culture on financial reporting configuration, or the non-compliance costs, either related to corporate governance mechanism or state enforcement, sum-up the motivation for earnings management.

On these circumstances, it is essential to understand the causal relation between macroeconomic estimates and quality of financial statements. This relation is best, described by the income approach used to calculate GDP, which underline the role of the operating income on the equation of GDP. Until now there has been little interest paid on the impact of financial statements quality on the accuracy of macroeconomic estimates. There are studies that underline the decline in value relevance of the financial information, especially concerning financial performance (Dichev \& Tang, 2008; Hail, 2013; Lev, 2018). Overall, those studies underline the fact that the objective of

\footnotetext{
* Corresponding author. E-mail address: burca_valentin@yahoo.com
} 
stewardship become more and more important, while the objective of valuation of the financial statements become less important. Consequently, the predictability of financial information is affected negatively, with implications on the equation used to forecast GDP level.

In spite of those results, there are more recent studies that show financial statements are still useful on forecasting macroeconomic aggregates, such as Konchichki \& Patatoukas (2013), Nallareddy \& Ogneva (2017), Abdalla \& Carabias (2017), Lechien (2017), Park et al. (2018), Gaertner et al. (2019), or Patatoukas (2020) that underline the role of financial statements in economic growth estimation. There are also studies that emphasize the value relevance of financial statements on unemployment rate estimation, such as Kalay et al. (2014).

However, we have to underline the fact that those articles have focused on analyzing the value relevance of financial statements on the projection of macroeconomic estimates, without looking on the role of the accounting and auditing regulation. As Dichev et al. (2013) underlined, standard setting has a first-order effect on the utility of earnings. After all, the framework for accounting practice is, or should be the accounting regulation. On this area, only Friedman (2015), Lazarov et al. (2017) and Tiron-Tudor \& Achim (2019) have brought some insights.

The main purpose of our study is to assess the marginal effect of the quality of financial statements and the quality of accounting regulation on the economic growth estimates precision. As GDP growth estimates depend on a long list of economic, social, regulatory and political drivers, we want to integrate firm-specific earnings quality information and strength of accounting and auditing regulation in a complex model of path analysis, along with macroeconomic context vector of variables. This way we analyze the role of accounting regulation on estimating economic growth. Is there a direct or indirect significant effect of the strength of accounting and auditing regulation on the macroeconomic estimates? Are earnings quality positively affected by a stronger accounting and auditing regulation framework? Is macroeconomic context facilitating the increase of earnings quality through a strong accounting and auditing regulation framework? All those questions are to be replied through the path analysis we performed, providing us useful information about the complexity of the causal relations between macroeconomic drivers, national accounting framework, accounting practice and macroeconomic aggregates.

\section{LITERATURE REVIEW AND HYPOTHESIS DEVELOPMENT}

Macroeconomic estimation models are designed to use either information provided through regular statistical surveys within companies, or information disclosed through financial statements (EU Regulation, 2013). Constrained by the degree of standardization of financial statements content and format, the level of digitalizing financial statements and the access national accounts experts have to the database of all financial information disclosed by companies, the methodology of compilation of national accounts as directly affected by financial statements quality.

However, there are studies that underline the decline in quality of financial statements, revealing the trend that strengthen the objective of stewardship of the financial statements (Dichev \& Tang, 2008; Hail, 2013; Lev, 2018). The decline seems to be even more prominent on the financial performance level, mainly because of the use of earnings management techniques, as managers want to get advantage of incentives generated by capital markets (Kothari, 2001; Dechow et al., 2010; Leuz \& Wysocki, 2016).

The use of earnings management techniques seems to be a systematic issue, most probably as a consequence of an accounting regulation not sufficiently connected to the economic reality and insufficient or ineffective enforcement controls designed to ensure an acceptable level of compliance of accounting and financial reporting practice. Studies such as of Graham et al. (2006) underline the negative effects of earnings management practice, which seem to be used by top management as long as there are identified ways to manipulate financial information complying 
with legal requirements, no matter the potential of long-term economic growth of a company is sacrificed. In the end, even managers admit they proceed to earnings management, in order to ensure a long-term stability of earnings and a proper correlation with cash flows (Dichev et al., 2013). On those circumstances, managers' freedom on decision-making has been limited through debt-contracting techniques that establish constraints on firms' strategic decisions, monitored through different balance-sheet-based covenants, or financial performance covenants, with implications on firms’ risk profile and cost of financing (Christensen \& Nikolaev, 2012).

In spite of this overall picture concerning quality of financial statements, more recent studies have assessed the causal relation between macroeconomic estimates accuracy and earnings quality.

Konchichki \& Patatoukas (2013) are pioneers on this research area, emphasizing the value relevance of aggregate accounting earnings growth in the prediction of growth in nominal GDP. However, the study underline the fact that financial information is not fully incorporated into the macroeconomic estimates, as only financial information revealed within 1-2 quarters in advance seem to be relevant in macroeconomic prediction models. Similar finding was confirmed on studies such as Lechien (2017) or Park et al. (2018).

A root cause might be the accounting conservatism of the financial information disclosed, that can deter value relevance of financial information generating a discretionary lag of time for positive earnings reported, with impact on GDP growth estimates that does not incorporate financial information timely (Hann et al., 2012; Do \& Nabar, 2018; Gartner et al., 2019). Another consequence is the calendar of financial reporting itself, as it does not fit to the calendar of macroeconomic estimates projection. Together with the conditional conservatism and the fact that analysts use alternative sources of information, even if they are only estimates, this lag in time between the two calendars generate late integration of financial information into macroeconomic estimates and with lower power of predictability (Konchichki \& Patatoukas, 2013; Lalwani \& Chakraborty, 2020).

Those results determined researchers to overcome this issue. Alternative solution for traditional economic growth forecast seem to be the now-casting models (Chen \& Ranciere, 2016; Abdalla \& Carabias, 2017; Park et al., 2018; Ferrera \& Simoni, 2019). With help of those models and together with information technologies related to web data collection and data mining techniques, macroeconomic estimates can be made with higher precision, on a short-term base. However, it has to be underlined the fact that short-term estimates can be significantly biased by irrational behavior of investors, as on short-term most of information is related to analysts estimates and management corporate interim financial disclosures, which are not subject of audit certification.

Another root cause is highlighted by Konchichki \& Patatoukas (2013) that brings to our attention the fact that financial information is only partially integrated in macroeconomic estimates of GDP growth because analysts prefer to use information that is oriented to the capital market evolutions, sacrificing aspects disclosed by financial statements related to economic substance of firms' operations. Hence, the impact of earnings quality, significantly driven by capital-markets incentives, amplifies the negative effect of low earnings quality into the macroeconomic estimates errors.

As macroeconomic estimates origin is the national accounts system, similar to firms' accounting system in many aspects, including the use of accruals accounting, the studies revealed that cashflow information is less value relevant in macroeconomic estimates projection than accruals accounting information (Konchichki \& Patatoukas, 2013; Park et al., 2018). In the end, information related to cash flows has a higher level of variation along the time, which translate into higher standard deviations and lower consistency of the prediction models.

Because of using aggregate earnings, value relevance of financial information decrease drastically in case of selection of homogenous sample of firms, which did not report extraordinary items. Indeed, as Gaertner et al. (2012) and Ball \& Sadka (2015) have underlined, the aggregation of 
earnings reported lead to a compensation effect, which could deter the value relevance of financial statements to provide insightful information related to prediction on economic growth. Hence, studies like Nallareddy \& Ogneva (2017), Carabias (2017), or Gaertner et al. (2019) have demonstrated financial information become more relevant for macroeconomic GDP growth estimates as long as it reflect high variance in earnings reported, providing clues about potential future economic shocks. Moreover, seem that revised macroeconomic estimates related to economic growth have a higher correlation with the variance of earnings reported than with the mean of earnings reported (Nallareddy \& Ogneva, 2017). Thus, the error of macroeconomic estimation is correlated with the variance on earnings reported, while the mean of earnings reported is correlated with the economic estimation.

Consequently, we consider for testing the following hypothesis:

$\mathbf{H}_{1}$ : earnings quality generate a positive impact on macroeconomic estimates precision.

Related to the impact of IFRS adoption on the accuracy of macroeconomic estimates, the literature does not provide unanimous conclusion. There are studies that confirmed through various empirical studies that IFRS adoption can lead to increase in quality of earnings reported (De George, 2016). Similar results are obtained by Park et al. (2018) that confirm IFRS adoption generate a significant increase of earnings quality on the precision of macroeconomic estimates. However, Huang (2015) could not confirm a significant causal relation between earnings quality and macroeconomic estimates accuracy. Seem there is little interest of researchers on this area, because of design issue to isolate the effect of IFRS adoption on the evolution of macroeconomic estimates accuracy.

Still the results reflecting effect of IFRS adoption on earnings quality are conditioned by enforcement mechanisms effectiveness (Christensen et al., 2013; Barth \& Israeli, 2013) or economic incentives (Daske et al., 2008; Armstrong et al., 2010; Daske et al., 2013; Christensen et al., 2015). IFRS adoption has not solved the problem of accounting differences, neither on national level, nor on international level. Nobes (2015) has illustrated how the overt, covert and measurement options, allowed by IFRS as a political compromise, determine still wide spread of accounting practice, because of political factor, cultural dimension and economic and reputational managers' objectives.

There are studies that ask for research to study marginal effect of accounting regulation on macroeconomic output, as there is lack of such studies (Leuz \& Wysocki, 2016). IFRS adoption was a good exercise to isolate the impact of accounting regulation from other factors, such tax regulation, corporate governance, enforcement framework, or cultural dimension (DeGeorge, 2016). Such study is of Christensen et al. (2015) that underline the fact that reporting incentives dominate accounting standards in determining accounting quality, especially in case of voluntary adoption of IFRS. The equation become even more complicated if we consider the nature of the standard-setting process, which is highly impacted by the political factor and cultural dimension of financial reporting.

However, it is essential to understand if accounting regulation at least facilitate the increase in earnings reported and if the indirect effect on macroeconomic estimates accuracy is significant or not. Currently there are few studies assessing the macroeconomic output of high-quality accounting standards. As the quality of accounting standards is a latent characteristic that cannot be directly measured, Friedman (2015) and Lazarov et al. (2017) have studies how the perception on the strength of accounting and auditing regulation generate effects on capital markets level and economic growth. Both studies have achieved to confirm a positive correlation between the evolutions of capital markets and the perception on the strength of accounting and auditing regulation. More exactly, the results reveal that higher perception on the strength of accounting and auditing standards, is related to higher market value for companies reporting in compliance with those accounting and auditing standards. Moreover, Tiron-Tudor \& Achim (2019) have confirmed a 
significant role of higher perception on the strength of accounting and auditing standards on capital markets price synchronicity.

In spite of expected indirect effect of accounting standards on the evolutions of capital markets, Friedman (2015) and Lazarov et al. (2012) as well have underlined that the marginal effect of SARS score (strength on auditing and reporting standards) is higher than the one related to GDP, leading to the conclusion that quality of accounting and auditing standards is at least as important as the level of economic development. On the other side, Tiron-Tudor \& Achim (2019) obtain contradictory results related to SARS score, as price synchronicity in the market is mainly ensured by an institutional framework supported only by a highly developed economy.

Consequently, we consider for testing the following hypothesis:

$\mathbf{H}_{2}$ : perceived quality of accounting and auditing standards influence positively macroeconomic estimates precision.

However, as revealed by Christensen et al. (2013) and Barth \& Israeli (2013), the benefits of highquality accounting regulation are conditioned by the effectiveness of the enforcement framework. Further, Lazarov et al. (2017) highlight the role of the effectiveness of firm level corporate governance mechanisms, which are perceived as complementary tools to facilitate the positive premises on earnings quality generated by high quality accounting standards.

On those circumstances, it is essential to capture in our analysis, not only the role of accounting regulation on the precision of macroeconomic estimates, or the impact of quality of earnings reported, but also the influence of a wider range of factor such as:

$>$ macroeconomic context;

$>$ nature of the standard-setting process and influence of political factor;

$>$ the cultural dimension on financial reporting;

effectiveness of enforcement framework.

\section{METHODOLOGY RESEARCH}

Our research paper starts from several open questions raised by Leuz \& Wysocki (2016) that highlight there is not sufficient focus on the research of the outcomes of disclosure and reporting regulation. Ball (2008) underline the fact that there is no yet clear which is the leading factor that influence significantly financial reporting practice. Is it capital market that has a dominant effect on financial reporting practice, or the accounting regulation that is affected by the political factor inferences? Is there a link between accounting regulation and economic growth? Alternatively, accounting regulation ensure only the premises of better quality of earnings reported, that translate into better macroeconomic estimates precision? How macroeconomic context, the nature of standard-setting process or cultural dimension relate to accounting regulation, or the accuracy of macroeconomic estimates concerning economic growth? All these questions capture a complex network of causal relations defining the framework that help us to describe the influence of quality of financial statements on the macroeconomic estimates precision. This is the reason why we proceed to a path analysis, in order to describe the conceptualization of the complex causal relations between all those elements.

Compared to the traditional regression analysis that give each variable considered in the model the same ontological position towards the dependent variable, path analysis is an extension that allow a hierarchical ordering of the variables, based on the direct or indirect effect they have on the dependent variable (Rotariu et al., 2006). Path analysis support researchers to overcome the weaknesses implied by Ceateris Paribus assumption, that does not provide all the time consistent evidence related to causal relations between elements composing a complex system. Using this model help researcher as well to solve partially the problem of endogeneitiy, as path models capture not only the relation between final dependent variable, but also the relations between independent variables as well through simple linear regression equations. 


\section{Model specification}

Model specification refer to the path diagram we conceive, based on literature review. Our path diagram focuses on accounting related variables and less on other traditional factors, as the scope of our paper is to study the influence of the quality of financial statements on the macroeconomic estimates precision. The impact of this limitation of the model is going to be visible through the coefficient of determination of the model. As long as our model has a high level of $R^{2}$, we can conclude on a significant influence of accounting regulation and quality of financial statements on the accuracy of macroeconomic estimates.

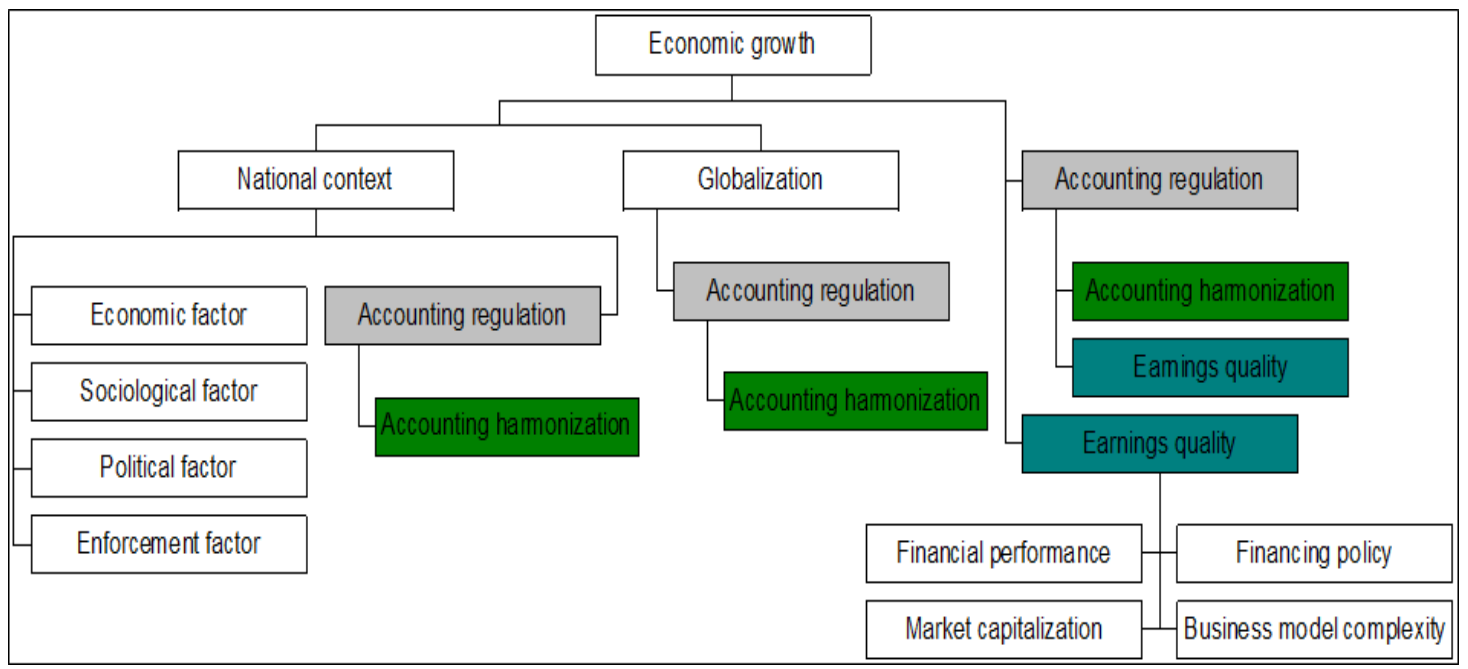

Figure 1. Causal relations landscape, bottom-down approach Source: own projection

According Figure 1 the precision of economic growth predictions is influenced by the quality of accounting regulation, through a direct path. Accounting regulation is expected as well to facilitate optimization of macroeconomic estimates precision, though earnings quality channel, as long as firms' corporate governance controls and state enforcement mechanisms prove to be effective on ensuring compliance of accounting practice with the legal framework (Christensen et al., 2013; Barth \& Israeli, 2013). As long there is a large number of research papers that have addressed the topic of effects generated by IFRS adoption on the quality of the financial statements and on the efforts to rethink national standard setting processes, we have considered in our path diagram a variable that describe the level of harmonization of local GAAP with IFRS.

Country profile has also an influence on the definition of accounting regulation, through tax regulation, investors' protection legislation, economic development, capital markets maturity, nature of legislative system, nature of standard setting process, cultural values and principles, institutional framework of regulation enforcement, or accounting profession (Nobes \& Parker, 2010). Consequently, we analyze the strength of perception on accounting regulation from perspective of how national context can influence accounting and auditing regulation, to ensure the sensitivity of the model to country level characteristics.

As nowadays the globalization process is irreversible, we search as well for the impact of the phenomenon on supporting the efforts of national standard setters to harmonize local GAAP with international financial reporting framework.

Corporate governance mechanisms work symbiotically with the financial reporting system on firm level (Bushman \& Smith, 2001; Cohen et al., 2004; Armstrong et al., 2010; Dechow et al., 2010). 
In addition, financial information seems to become extremely important in debt contract, in the light of increasing practice of earnings management (Armstrong et al., 2010; Nikolaev, 2012; Leuz \& Wysocki, 2016). All these studies have underlined the essential role of financial statements and the signal managers transmit to the capital markets. One recent example of such systemic issue was described by Daske et al. (2013) that have revealed there are firms that actually adopt IFRS just with the purpose to give false signals to investors about their financial position and financial performance. In order to control this behavior we have considered firms specific characteristics as well, to ensure robustness of the model. Firm characteristics are not related to country specific variables in our path diagram, as we observe in Table 1, there is a low level of Pearson correlation among those variables.

Table 1. Correlation matrix based on sample data

\begin{tabular}{|c|c|c|c|c|c|c|c|c|c|c|c|c|c|}
\hline & \multirow[b]{2}{*}{$\begin{array}{l}\text { Earnings } \\
\text { quality }\end{array}$} & \multicolumn{7}{|c|}{$\begin{array}{l}\text { Firm specific } \\
\text { characteristics }\end{array}$} & \multicolumn{5}{|c|}{ Country specific characteristics } \\
\hline & & SARS & $\begin{array}{l}\text { GDP } \\
\text { growth }\end{array}$ & Lev. & EPS & ROA & Size & $\begin{array}{c}\text { Acc. } \\
\text { Harmoni } \\
\text { zation }\end{array}$ & $\begin{array}{l}\text { Globaliz } \\
\text { ation }\end{array}$ & $\begin{array}{l}\text { Econo } \\
\text { mic }\end{array}$ & $\begin{array}{l}\text { Sociolo } \\
\text { gical }\end{array}$ & $\begin{array}{c}\text { Politi } \\
\text { cal }\end{array}$ & $\begin{array}{l}\text { Regula } \\
\text { tory }\end{array}$ \\
\hline Earnings quality & 1 & & & & & & & & & & & & \\
\hline SARS & $.097^{* *}$ & 1 & & & & & & & & & & & \\
\hline GDP growth current & $-.040^{*}$ & $-.064^{* *}$ & 1 & & & & & & & & & & \\
\hline Lev. & $-.274^{* *}$ & $-0,020$ & 0,029 & 1 & & & & & & & & & \\
\hline EPS & $-.165^{* *}$ & $-.036^{*}$ & $-0,007$ & $-0,005$ & 1 & & & & & & & & \\
\hline ROA & $1.000^{* *}$ & $.097^{* *}$ & $-.040^{*}$ & $-.274^{* *}$ & $-.165^{* *}$ & 1 & & & & & & & \\
\hline Size & $-.187^{* *}$ & $-0,027$ & $.075^{* *}$ & $.323^{* *}$ & $-0,022$ & $-.187^{* *}$ & 1 & & & & & & \\
\hline Accounting Harmonization & $.045^{* *}$ & $-.226^{* *}$ & $-0,029$ & 0,019 & $-0,017$ & $.045^{* *}$ & $.063^{* *}$ & 1 & & & & & \\
\hline Globalization & $.155^{* *}$ & $.431^{* *}$ & $-.249^{* *}$ & $-.071^{* *}$ & 0,002 & $.155^{* *}$ & $-.054^{* *}$ & $-.293^{* *}$ & 1 & & & & \\
\hline Economic & $.160^{* *}$ & $.537^{* *}$ & $-.197^{* *}$ & $-.040^{*}$ & $-0,011$ & $.160^{* *}$ & $-.060^{* *}$ & $-.168^{* *}$ & $.704^{* *}$ & 1 & & & \\
\hline Sociological & $.166^{* *}$ & $.362^{* *}$ & $.098^{* *}$ & $-.084^{* *}$ & $-0,009$ & $.166^{* *}$ & $-.051^{* *}$ & $.117^{* *}$ & $.500^{* * *}$ & $.140^{* *}$ & 1 & & \\
\hline Political & $.175^{* *}$ & $.237^{* *}$ & $.064^{* *}$ & $-0,030$ & $-0,024$ & $.175^{* *}$ & $-0,004$ & $.630^{* *}$ & $.263^{* *}$ & $.529^{* *}$ & $.354^{* *}$ & 1 & \\
\hline Regulatory & $.040^{*}$ & $.131^{* *}$ & $-0,016$ & $-0,014$ & $-0,002$ & $.039^{*}$ & $-0,005$ & $-0,014$ & $.188^{* *}$ & $-.372^{* *}$ & $.633^{* *}$ & $-.213^{* *}$ & 1 \\
\hline
\end{tabular}

Source: statistics performed with SPSS 25.0

Additional covariate relations are considered in our model, as marked on the correlation matrix calculated based on our sample data and reflected on Figure 2. We considered covariate relations within firms' characteristics only in case of the pairs of variables described by statistical significant correlation. In case of country specific variables, we have considered covariate relations on our path model only for the pairs of variables described by statistical significant correlation greater than 0.500 . Sample data and variables definition

Our sample consist of 3466 companies for which we could have retrieved financial information from ORBIS database, in order to avoid any missing data for variables included in our path analysis model. The sample of companies is spread within 14 countries, with a higher weight of companies originating from United Kingdom (23.89\%), Germany (16.79\%), France (16.16\%) and Sweden (11.37\%). On those circumstances, our estimates will not necessarily be biased by the nature of the accounting system, as the accounting system for each of the mentioned countries differ significantly (La Porta et al., 2008).

The period analyzed is 2016-2018. Sample data are analyzed using SPSS package. For path model estimation, we use SPSS AMOS module, integrated in SPSS package.

Variables considered in our analysis are defined in Table 2. 


\begin{tabular}{|c|c|c|c|c|}
\hline \multicolumn{5}{|c|}{ Table 2. Definition of variables included in path model estimated } \\
\hline Variable & $\begin{array}{l}\text { Path } \\
\text { coeff. }\end{array}$ & Description & Formula & Source \\
\hline $\begin{array}{l}\text { GDP growth } \\
\text { estimation }\end{array}$ & $a_{i->13}$ & $\begin{array}{l}\text { - measures the error in } \\
\text { estimation of GD } \\
\text { growth, in percentage; }\end{array}$ & 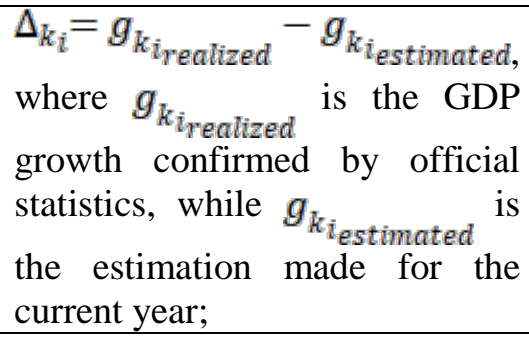 & IMF database \\
\hline SARS & $a_{i}>12$ & $\begin{array}{l}\text { - it is a measure of } \\
\text { perception concerning } \\
\text { the strength of auditing } \\
\text { and reporting standards } \\
\text { for a country, as from } \\
\text { investors perspective }\end{array}$ & 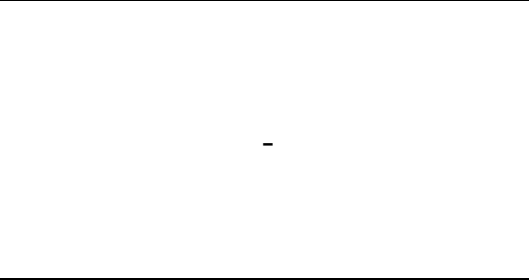 & $\begin{array}{c}\text { Global } \\
\text { Competitiveness } \\
\text { Report }\end{array}$ \\
\hline Earn. quality & $a_{i}>11$ & $\begin{array}{l}\text { - it is a measure of } \\
\text { earnings quality } \\
\text { assessing the } \\
\text { amplitude of reported } \\
\text { accruals, as defined in } \\
\text { Dechow et al. (2010); }\end{array}$ & $\frac{\text { Net }_{\text {Income }} \text { Cash }_{k_{i}}}{\text { Calow }_{k_{i}}}-1$ & $\begin{array}{l}\text { Calculated based } \\
\text { on data extracted } \\
\text { from ORBIS } \\
\text { database }\end{array}$ \\
\hline $\begin{array}{c}\text { Accounting } \\
\text { harmonization }\end{array}$ & $a_{i}>10$ & $\begin{array}{l}\text { - this is an aggregate } \\
\text { measure of the level } \\
\text { of adoption of } \\
\text { international } \\
\text { framework in the area } \\
\text { of firm accounting } \\
\text { (IFRS), government } \\
\text { accounting (IPSAS), } \\
\text { accounting education } \\
\text { (IES) and auditing } \\
\text { (ISA); }\end{array}$ & PCA analysis & $\begin{array}{l}\text { Calculated based } \\
\text { on IFAC status } \\
\text { report }\end{array}$ \\
\hline Globalization & $a_{i->9}$ & $\begin{array}{l}\text { - capture the level of } \\
\text { globalization for each } \\
\text { country, through KOG } \\
\text { index designed as per } \\
\text { Dreher et al. (2008); }\end{array}$ & - & $\begin{array}{c}\text { KOF Swiss } \\
\text { Economic } \\
\text { Institute database }\end{array}$ \\
\hline Economic & $a_{i->8}$ & \multirow{4}{*}{$\begin{array}{l}\text { - aggregate measure } \\
\text { describing economic } \\
\text { context, as defined by } \\
\text { Isidro et al. (2019); }\end{array}$} & \multirow[t]{4}{*}{ - } & \multirow{4}{*}{ Isidro et al. (2019) } \\
\hline Sociological & $a_{i->7}$ & & & \\
\hline Political & $\mathrm{a}_{\mathrm{i}->6}$ & & & \\
\hline Regulatory & $a_{i->5}$ & & & \\
\hline ROA & $\mathrm{a}_{\mathrm{i}->4}$ & - assets profitability rate; & - & \multirow{2}{*}{$\begin{array}{l}\text { Extracted from } \\
\text { ORBIS database }\end{array}$} \\
\hline EPS & $a_{i->2}$ & - earnings price ratio; & - & \\
\hline Leverage & $a_{i->3}$ & - financial leverage; & $\frac{\text { Total Debt }}{\text { Total Capital }_{k_{i}}}$ & \multirow{2}{*}{$\begin{array}{c}\text { Calculated based } \\
\text { on data extracted } \\
\text { from ORBIS } \\
\text { database }\end{array}$} \\
\hline Size & $\mathrm{a}_{\mathrm{i}->1}$ & - business complexity; & $\ln \left(\right.$ Total assets $\left.k_{k_{i}}\right)$ & \\
\hline
\end{tabular}

Source: own projection 


\section{Model estimation}

To estimate the parameters of our path diagram, Maximum Likelihood method was used for path analysis parameters estimation. Structural equations, similar to multiple regression models, are estimated by minimizing discrepancy function between the sample covariance matrix $(S)$ and the covariance matrix $\Sigma(\theta)$ resulted from the path model, where:

- $\quad \Sigma$ is the population covariance matrix for observed variables;

- $\theta$ is the vector containing model parameters.

Starting from left to right in the path diagram, the regression equations are estimated for each endogenous variable included in the model, based on the data available for the exogenous and endogenous variables included in each regression model. We define first the structural equation that describe all variables that affect SARS score, according our path diagram, as per relation (1):

$$
\text { SARS }=a_{10,12} \cdot \text { Harm. }+a_{8,12} \cdot \text { Eco. }+a_{7,12} \cdot \text { Socio. }+a_{6,12} \cdot \text { Pol. }+a_{5,12} \cdot \text { Reg. }+a_{9,12} \cdot \text { KOF }+a_{e_{1}} \cdot e_{1}
$$

In the next step, we define the next level of our path diagram involving SARS score influence, namely relation (2), related to earnings quality endogenous variable:

$$
\text { Earn. }=a_{12,11} \cdot \text { SARS }+a_{10,11} \cdot \text { Harm. }+a_{4,11} \cdot \text { ROA }+a_{3,11} \cdot \text { Lev. }+a_{2,11} \cdot \text { EPS }+a_{1,11} \cdot \text { Size }+a_{e_{2}} \cdot e_{2}
$$

As a final step, we define the structural equation related to our final endogenous variable, respectively relation (3) corresponding to GDP growth estimation accuracy in our path analysis:

$$
\begin{aligned}
& g_{k_{i}}=a_{12,13} \cdot \text { SARS }+a_{11,13} \cdot \text { Earn. }+a_{8,13} \cdot \text { Eco. }+a_{7,13} \cdot \text { Socio. }+a_{6,13} \cdot \text { Pol. }+a_{5,13} \cdot \text { Reg. }+a_{9,13} \cdot \\
& \text { KOF }+a_{e_{2}} \cdot e_{3}
\end{aligned}
$$

For robustness analysis, we will proceed as well to decomposition of effects, relating to country specific characteristics and firms specific characteristics, as described on Table 2 . With that analysis, we intend to check if accounting regulation mediate further economic growth. Additional analysis consists of the assessment of the level accounting regulation facilitate the state to meet its objectives in terms of compliance of accounting practice with legal regulation, as highlighted by Christensen et al. (2013), or Barth \& Israeli (2013).

\section{RESULTS AND DISCUSSION}

According international financial reporting framework, the objective of financial statements is to provide financial information useful for shareholder, potential investors and other stakeholders in the decision-making process (CF, 1.2). That information have to depict a faithful and value relevant image of the economic resources of the entity and the efficiency and effectiveness of resources allocation (CF, 1.4.). Our results focus on the analysis of value relevance of financial statements, useful on the projection of macroeconomic estimates.

According Table 4, accruals accounting impact on financial statements seem to be spread on a wide range of values, from -0.005 to 67.80 illustrating the specific of each firm's earnings management policy. Also, the mean of 6.94 seem to be closer to the minimum value, that lead us to the conclusion that accounting accruals seem to be relatively low, with consequences on financial information predictability (Scott, 2015). As long as accruals reported are not discretionary, accruals accounting can ensure a higher predictability of financial information. However, mean standard error of 0.102 is way lower than the mean which is 6.94 . 


\section{Table 4. Descriptive statistics}

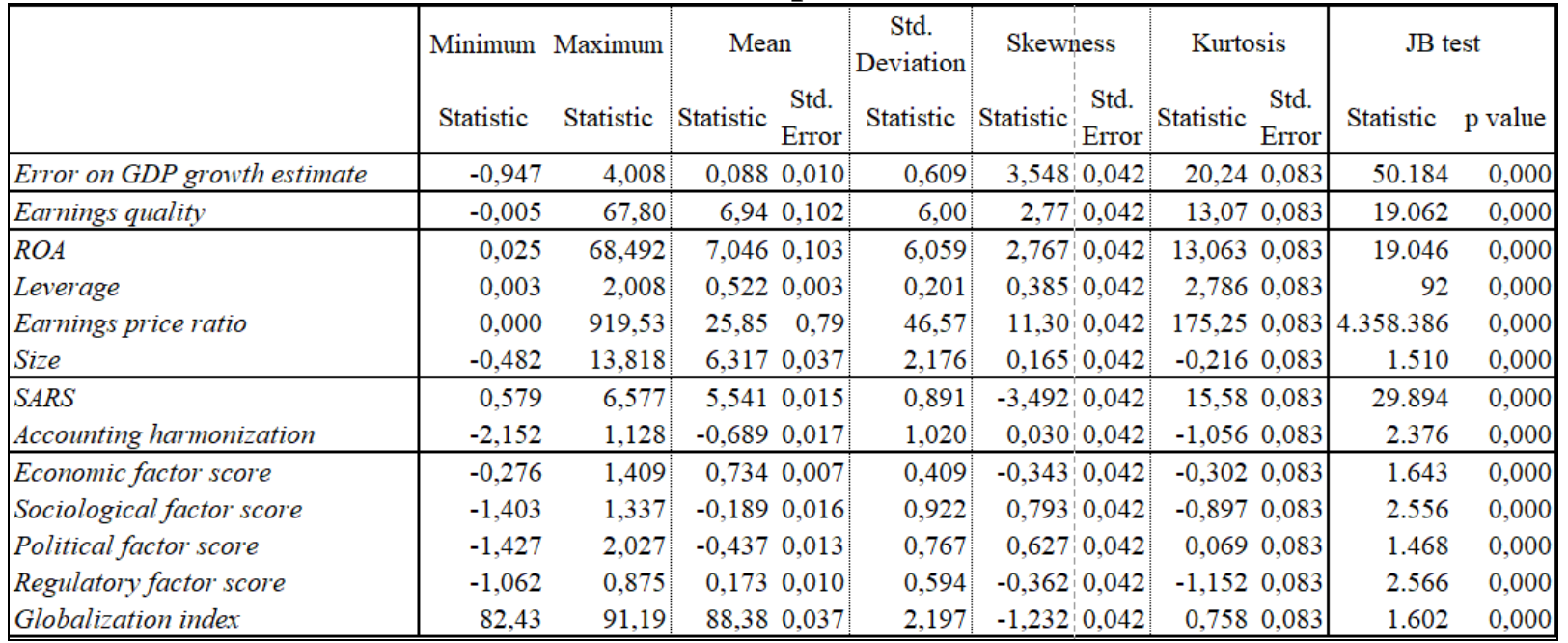

Source: statistics performed with SPSS 25.0

We observe this spread also in case of ROA and EPS. As the variation in total assets (size) is lower than the variance in ROA, we get some indices that earnings reported have a high variance among our sample. As emphasized by Hail (2013), seem the variance is visible especially for financial performance element reported, implying managers proceed to earnings management. This assertion is supported also by the variance on firms' financial leverage, that represent a constraint for managers to achieve targets negotiated with creditors in terms of financial performance covenants.

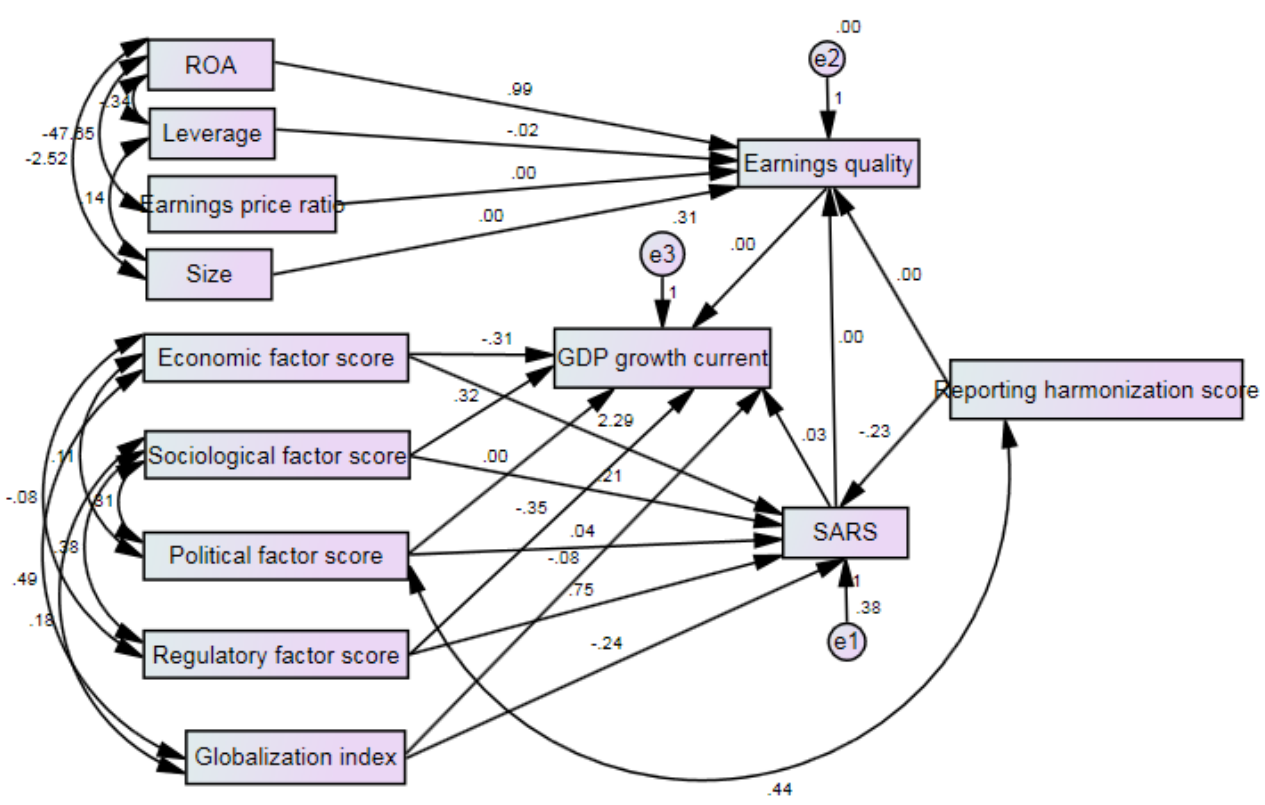

Figure 2. Path diagram with estimated parameters (unstandardized value) Source: statistics performed with AMOS 22.0

If we look to the variance in SARS score, we observe the perception on the strength of countries' auditing and reporting standards is more homogenous than the evidence provided related to earnings quality, as standard deviation of 0.891 is significantly lower than the mean of 5.541. This evidence might be caused by the fact that this score is just a measure of perception, as noted by Friedman (2015), instead of an empirical comparison of local GAAP with IFRS. However, those results are interesting as the mean of 5.541 translate into a high level of our score, as the maximum score 
possible is 6.577. Those results were expected, as countries included in our sample are known having really mature accounting and auditing framework.

On the other hand, statistics still emphasize a high resistance to the initiatives of international harmonization of local auditing and accounting standards with the international framework. The score capturing the level of adoption of international accounting and auditing framework on a national regulation level has a deviation of 1.020 significantly higher than the mean score of -0.689 . As Nobes (2011) noted, the experience of IFRS is not necessarily a positive one, as the international reporting framework was adopted according different scenarios along the countries, which preserve national standard setters' power of regulation.

In Figure 2 we capture the path diagram of our path analysis model. In Table $\mathbf{5}$ we have synthesized the main statistics of our structural equations. Overall, we observe that all structural equations are valid, as their $R^{2}$ is relatively high. Most of parameters are confirmed statistically significant with a significance level of $1 \%$.

Table 5. Path model parameters

\begin{tabular}{|c|c|c|c|c|c|}
\hline $\begin{array}{c}\text { Endogenous } \\
\text { variable }\end{array}$ & & Exogenous variable & Estimate $^{1}$ & S.E. & $\mathbf{R}^{2}$ \\
\hline \multirow{4}{*}{ SARS } & $<---$ & Economic factor & $2.291 *$ & 0.068 & \multirow{6}{*}{0.62} \\
\hline & $<---$ & Sociological factor & $0.206^{*}$ & 0.022 & \\
\hline & $<---$ & Political factor & 0.041 & 0.034 & \\
\hline & $<---$ & Regulatory factor & $0.755^{*}$ & 0.032 & \\
\hline SARS & $<--$ & KOF index & $-0.242^{*}$ & 0.008 & \\
\hline SARS & $<---$ & Harmonization score & $-0.231 *$ & 0.018 & \\
\hline \multirow{4}{*}{ Earnings quality } & $<<--$ & $\mathrm{ROA}$ & 0.99* & 0 & \multirow{6}{*}{1} \\
\hline & $<---$ & Leverage & $-0.015^{*}$ & 0.003 & \\
\hline & $<---$ & EPS & 0 & 0 & \\
\hline & $<---$ & Size & $0.001 * * *$ & 0 & \\
\hline Earnings quality & $<---$ & SARS & 0 & 0.001 & \\
\hline Earnings quality & $<---$ & Harmonization score & 0 & 0.001 & \\
\hline GDP growth & $<--$ & Earnings quality & $-0.003 * *$ & 0.002 & \multirow{7}{*}{0.69} \\
\hline \multirow{4}{*}{ GDP growth } & $<<--$ & Economic factor & $-0.307^{*}$ & 0.065 & \\
\hline & $<---$ & Political factor & 0.002 & 0.018 & \\
\hline & $<---$ & Sociological factor & $0.316^{*}$ & 0.017 & \\
\hline & $<---$ & Regulatory factor & $-0.352 *$ & 0.031 & \\
\hline GDP growth & $<--$ & KOF index & $-0.082 *$ & 0.008 & \\
\hline GDP growth & $<---$ & SARS & $0.033 * *$ & 0.015 & \\
\hline
\end{tabular}

Source: statistics performed with SPSS 25.0

According our results, seem countries' political system is not relevant, neither on SARS score, nor on the error of the economic growth estimation. Root cause behind our results are various. However, as we talk about accounting standard models in our sample, such as United Kingdom, Germany, France, Italy or Spain, investors might give less importance to the politics behind standard-setting process, as the process is sufficiently mature. Our results are contradictory with results of Boolaky et al. (2013) that have confirmed a significant role of the legal framework (seen as an output of the political factor) on investors' perception about the strength of the auditing and accounting standards. 
In spite of those results, Boolaky et al. (2013), same as Friedman (2015), or Pop (2018), could not have confirmed as well a significant influence of legal framework on SARS score, when looking for simultaneous impact of other factors as well, such as the maturity of capital markets and related national enforcement framework. Our results provide similar insights, as SARS score main drivers seem to be the economic factor, with a positive marginal impact of 2,291, and the regulatory factor, with a positive marginal impact of 0,755 . Hence, investors' perception on the strength of auditing and accounting standards is higher in case of highly developed economies, with a mature institutional framework ensuring enforcement of national regulation.

Not surprisingly is the small marginal influence of cultural and religious dimensions of the accounting standard-setting process on SARS score. As observed along the last decade, accounting standardsetters seem to support deregulation efforts, by inviting professionals and companies to participate in elaboration of new accounting standards. Therefore, the debate along cultural values and religious beliefs related to accounting regulation are placed in a second level and expertize in the field become more important. However, we do not have to neglect cultural and religion dimensions in the equation of accounting standard setting. Ex-ante cost-benefits analysis when analyzing effect of changes in accounting regulation is the solution to combat false assumptions implied by cultural and religious dimensions.

Interesting results are provided related to the relation between SARS score and earnings quality, respectively the relation between harmonization score and earnings quality. As underlined by Nobes \& Stadler (2015), even after IFRS adoption and implementation, international accounting differences persist because of existing overt, covert and measurements options that allow managers to smooth earnings under legal boundaries. Consequently, we see that quality of earnings reported is not significantly determined by the quality of accounting regulation. Hence, in spite a formal accounting harmonization exists, there is a lack of material accounting harmonization. Starting from the fact that SARS score is just a picture of investors' perception on the quality of auditing and accounting standards, we could justify our results with the fact that investors prefer to have more flexible accounting standards. However, the flexibility of accounting regulation has to be conditioned by compensating controls to ensure acceptable level of financial statements, such as better corporate governance processes focused on proper tracking of compliance of accounting practice with existing regulation, consistent efforts on promoting ethical behaviour within professionals, or financing of continuous improvement on professionals education.

Related to main drivers of the error amplitude in forecasting economic growth, we observe SARS score and earnings quality measure have significantly lower influence compared with countries' social, regulatory and economic profile. As expected, as long as quality of earnings reported is higher, the error in GDP growth forecasting reduces. However, marginal effect of earnings quality on the error of GDP growth forecasts of $-0,003$ is quite small. We would justify this result because of the low level of accruals, as reflected on the statistics from Table 4.

On the other side, as mentioned by Nobes (2015), adoption of IFRS on firms' level does not necessarily translate into higher quality of financial statements, as IFRS are more flexible than expected, allowing managers to proceed to earnings management. Our results confirm a positive causal relation between the error on GDP growth estimates and SARS score, meaning that the error in forecasting GDP growth increase in case of better perception on the quality of accounting regulation.

Most probably, investors benchmark local GAAP with international financial reporting framework when deciding the strength of accounting and auditing standards. As long as local GAAP are perceived as flexible, investors might refer to this as a potential range for managers to proceed to earnings management and thus deter earnings quality.

On the other hand, we could just refer to a gap between economic reality and accounting regulation. Nonetheless, if we refer to path coefficient related to economic factor and regulatory factor, we observe that as high is the quality of accounting regulation, compensating controls have to be implemented. Such controls can be translated into an effective enforcement institutional framework as emphasized by Christensen et al. (2013) and Barth \& Israeli (2013). Such enforcement mechanisms, 
either we talk about firm level corporate governance framework, or public institutions enforcement tools, have to be designed to ensure an acceptable level of firms compliance with regulation, including requirements related to accounting and financial reporting. As underlined by Sumiyana et al. (2019), highly developed economies have the possibility to finance such mature compensating controls, especially because firms operating in such economies are characterized by complex business model, with significant internationalization factor of the operations and a high degree of uncertainty.

\section{MODEL VALIDATION}

In Table 6 we summarize several tests useful for path model validation.

Table 6.Model fit indices for validation of path model

\begin{tabular}{lrc}
\hline \hline Selected fit indices & Statistic & $\begin{array}{c}\text { Decision on } \\
\text { model } \\
\text { validation }\end{array}$ \\
\hline Chi-square & 4.353 & \\
$d f$ & 48 & not valid \\
$p$ value & .000 & \\
\hline Root-mean-square error of approximation (RMSEA) & 0,161 & not valid \\
GFI & 0,893 & valid \\
Tucker-Lewis Index (TLI) & 0,877 & valid \\
Normed fit index (NFI) & 0,923 & valid \\
\hline
\end{tabular}

Source: statistics performed with AMOS 22.0

According Chi-square test, the model does not fit sufficiently our sample data. However, as Pituch \& Stevens (2016) underline, the test is sensitive to high sample size. As our sample consist of 3466 firms analyzed, model validation should be analyzed corroborating model fit indices. Except for RMSEA indices that exceed the 0.08 limit to confirm the model, the order indices keep close to the acceptable level that ensure model validation.

\section{CONCLUSIONS}

The problem of assessing drivers of the error in macroeconomic forecasting has been addressed along the time by numerous research papers. However, there is little evidence provided related to the role of financial statements on forecasting economic growth. Moreover, there has been paid even lower interest on the role of the quality of accounting regulation. Our study comes with some insights on those areas.

Related to earnings quality influence economic growth forecasts accuracy, our results emphasize the role of high-quality financial statements. As long as earnings reported are not affected by earnings management practice, financial statements could be used as source of data in forecasting economic growth, leading to improvement in estimates accuracy. However, the marginal influence seems to be small, compared with the one corresponding to the economic factor or the enforcement mechanisms implications.

We obtain interesting results concerning the influence of the perceived quality on accounting and auditing standards. We would have expected that high quality standards lead to an increase in accuracy for economic growth estimates. In spite of our expectations, the results show that better perception on the strength of accounting and auditing standards determine an increase in error for forecasted economic growth. Corroborated with the insignificant effect of accounting standards on earnings quality, we justify those results because of the gap existing accounting and auditing standards and respectively the economic reality. Therefore, accounting choice seem to be driven by 
capital markets incentives and compliance cost considerations. Hence, corporate governance mechanisms become essential towards the objective of high-quality financial statements, while markets monitoring tools have to prove their effectiveness on detecting any significant earnings manipulation, no matter managers find solutions following regulation requirements. As long as accounting regulation is too flexible, allowing managers to manage earnings, those compensating controls have to force managers to disclose true and fair information related to financial performance.

We have to underline that our study suffers some caveats. First of all, the period analyzed is limited to a period of only three years. Secondly, some robustness tests are opportune if we consider some longitudinal analysis, with focus on fixed effects generated by country or industry profile. Additionally, as Friedman (2015) highlighted, the study might be affected by the fact that our measure of quality for accounting regulation is limited to a measure of perception of investors on the strength of accounting and auditing regulation. Instead, this measure could be replaced by a construct confirmed by confirmatory factor analysis, based on data collected using questioners distributed to firms' CFOs and professionals. Nonetheless, we have to underline that institutional factors considered in the study might be too aggregate for the purpose of our research. Further research studies will consider an in-depth analysis of the topic, considering those weaknesses as well.

\section{REFERENCES}

Abdalla, A. \& Carabias J. M. (2017). From Accounting to Economics: The Role of Aggregate Special Items in Gauging the State of the Economy, working paper. Doi: 10.2139/ssm.2871600. Retrieved on August 01, 2020, from: https://papers.ssrn.com/sol3/papers.cfm?abstract_id=2871600.

Armstrong, C. S., Guay, W. R., \& Weber, J. P. (2010). The role of information and financial reporting in corporate governance and debt contracting. Journal of Accounting and Economics, 50 (2-3), 179-234.

Ball, R. (2008). What Is The Actual Economic Role of Financial Reporting? Accounting Horizons, 22 (4), 427-432. https://doi.org/10.2308/acch.2008.22.4.427

Ball, R. \& Sadka G. (2015). Aggregate earnings and why they matter. Journal of Accounting Literature, 34 (C), 39-57. Doi: 10.1016/j.acclit.2015.01.001

Barth, M. E., Israeli, D. (2013). Disentangling mandatory IFRS reporting and changes in enforcement. Journal of Accounting and Economics, 56 (2), 178-188. Retrieved on August 01, 2020, from: http://www.sciencedirect.com/science/article/pii/S0165410113000669

Boolaky, P. K., Krishnamurti, C., \& Hogue, A. (2013). Determinants of the Strength of Auditing and Reporting Standards: A Cross-Country Study. Australasian Accounting Business and Finance Journal, 7 (4), 17-36.

Bushman, R. M. \& Smith, A. J. (2001). Financial accounting information and corporate governance. Journal of Accounting and Economics, 32 (1-3), 237-333.

Chen, S., Ranciere, R. (2016). Financial Information and Macroeconomic Forecasts, working paper, available on https://www.imf.org/external/pubs/ft/wp/2016/wp16251.pdf

Christensen, H. B., Hail, L., \& Leuz, C. (2013). Mandatory IFRS reporting and changes in enforcement. Journal of Accounting and Economics, 56 (2-3), 147-177. Retrieved on August 01, 2020, from: http://www.sciencedirect.com/science/article/pii/S0165410113000645

Christensen, H. B., Lee, E., Walker, M., \& Zeng, C. (2015). Incentives or Standards: What Determines Accounting Quality Changes around IFRS Adoption? European Accounting Review, 24 (1), 31-61. https://doi.org/10.1080/09638180.2015.1009144

Christensen, H. B. \& Nikolaev, V. V. (2012). Capital Versus Performance Covenants in Debt Contracts. Journal of Accounting Research, 50 (1), 75-116. https://doi.org/10.1111/j.1475679X.2011.00432.x 
Cohen, J., Krishnamoorthy, G., \& Wright, A. (2004). The Corporate Governance Mosaic and Financial Reporting Quality. Journal of Accounting Literature, 23, 87-152.

Daske, H., Hail, L., Leuz, C., \& Verdi, R. (2008). Mandatory IFRS Reporting around the World: Early Evidence on the Economic Consequences. Journal of Accounting Research, 46 (5), 10851142.

Daske, H., Hail, L., Leuz, C., \& Verdi R. (2013). Adopting a Label: Heterogeneity in the Economic Consequences Around IAS/IFRS Adoptions. Journal of Accounting Research, 51 (3), 495-547.

Dechow, P., Gee, W., \& Schrand, C. (2010). Understanding earnings quality: A review of the proxies, their determinants and their consequences. Journal of Accounting and Economics, 50, 344-401.

De George E.T., Li, X., \& Shivakumar, L. (2016). A review of the IFRS adoption literature. Review of Accounting Studies, 21 (3), 898-1004. Retrieved on August 05, 2020, from: http://eprints.lse.ac.uk/67599/1/Xi_A_review_IFRS_adoption_literature.pdf

Dichev, I. D., Graham, J. R., Harvey, C. R., Rajgopal, S. (2013). Earnings quality: Evidence from the field. Journal of Accounting and Economics, 56 (2-3), 1-33. Retrieved on August 05, 2020, from: https://faculty.fuqua.duke.edu/ charvey/Research/Published_Papers/P114_Earnings_quality_evi dence.pdf

Dichev, I. D., Tang, V. W. (2008). Matching and the changing properties of accounting earnings over the last 40 years. The Accounting Review, 83 (6), 1425-1460.

Do, C. \& Nabar, S. (2018). Macroeconomic effects of aggregate accounting conservatism: A cross-country analysis . Journal of International Financial, Management \& Accounting, 30 (1), 83-107. https://doi.org/10.1111/jifm.12093

Dreher, A., Gaston N., \& Martens P. (2008). Measuring Globalization. Gauging Its Consequences. New York: Springer-Verlag New York. Doi: 10.1007/978-0-387-74069-0

Ferrera, L. \& Simoni, A. (2019). When are Google data useful to nowcast GDP? An approach via pre-selection and shrinkage, working paper, available on https://www.oecd.org/naec/neweconomic-policymaking/Ferrara_Simoni.pdf

Friedman, H. (2016). Capital market development and the (perceived) strength of financial auditing and reporting standards, working paper, available on https://papers.ssrn.com/sol3/papers.cfm?abstract_id=2587403

Gaertner, F., Steele, L., \& Kauser, A. (2019). The Usefulness of Negative Aggregate Earnings Changes in Predicting Future Gross Domestic Product Growth, working paper, available on https://papers.ssrn.com/sol3/papers.cfm?abstract_id=2656597

Graham, J. R., Campbell, R. H., \& Rajgopal, S. (2006). Value Destruction and Financial Reporting Decisions, Financial Analysts Journal, 62 (6), 27-39.

Hann, R. N., Ogneva, M., \& Sapriza, H. (2012). Forecasting the Macroeconomy: Analysts versus Economists, $\quad$ working paper, Available https://papers.ssrn.com/sol3/papers.cfm?abstract_id=2194179

Hail, L. (2013). Financial reporting and firm valuation: relevance lost or relevance regained? Accounting and Business Research, 43 (4), 329-358. Doi: 10.1080/00014788.2013.799402

Kalay, A., Nallareddy, S., \& Sadka G. (2014). Conditional Earnings Dispersion, the Macroeconomy and Aggregate Stock Return, working paper. Retrieved on August 05, 2020, from: https://www0.gsb.columbia.edu/mygsb/faculty/research/pubfiles/11552/nks_MS_not\%20blind.pdf

Konchichki, Y \& Patatoukas, P. N. (2013). Accounting earnings and gross domestic product. Journal of Accounting and Economics, 57, 76-88.

Kothari, S. P. (2001). Capital market research in accounting. Journal of Accounting and Economics, 31 (3), 105-231. Retrieved on August 20, 2020, from: https://www.sciencedirect.com/science/article/abs/pii/S0165410101000301

Lalwani, V. \& Chakraborty, M. (2020). Aggregate earnings and gross domestic product: International evidence. Applied Economics, 52 (1), 68-84. Doi: 10.1080/00036846.2019.1640859 
Lazarov, D., Lakovic, T., \& Kacarski, E. M. (2017). The Quality of Financial Information and Stock Market Development: A Panel Data Study for the European Economies, Included in: Jajuga K., Orlowski L., Staehr K. (eds) Contemporary Trends and Challenges in Finance. Proceedings from the 2nd Wroclaw International Conference in Finance. 145-153. Springer International Publishing. Doi: 10.1007/978-3-319-54885-2_14

Lechien, G. (2017). Taking the pulse of the real economy using financial statement analysis: the european perspective, working paper. Retrieved on August 10, 2020, from: https://run.unl.pt/bitstream/10362/36557/1/Lechien_2018.pdf

Leuz, C. \& Wysocki, P. D. (2016). The Economics of Disclosure and Financial Reporting Regulation: Evidence and Suggestions for Future Research. Journal of Accounting Research, 54 (2), 525-622. https://doi.org/10.1111/1475-679X.12115

Lev, B. (2018). The deteriorating usefulness of financial report information and how to reverse it. Accounting and Business Research, 48 (5), 465-493.

Nallareddy, S. \& Ogneva, M. (2017). Predicting Restatements in Macroeconomic Indicators Using Accounting Information. The Accounting Review, 92(2), 151-182. Available at: Doi: http://dx.doi.org/10.2139/ssrn.2444014

Nobes, C. W. (2011). IFRS Practices and the Persistence of Accounting System Classification. Abacus, 47(3), 267-283. https://doi.org/10.1111/j.1467-6281.2011.00341.x

Nobes, C. W. (2015). International differences in IFRS adoptions and IFRS practices, included in volume The Routledge Companion to Financial Accounting Theory, 167-196. New York: Routledge.

Nobes, C. W. \& Parker, R. (2010). Comparative International Accounting, $11^{\text {th }}$ edition. Harlow, Essex, U.K: Pearson Education Limited.

Nobes, C. W. \& Stadler, C. (2015), The qualitative characteristics of financial information and managers' accounting decisions: evidence from IFRS policy changes. Accounting and Business Research, 45 (5), 572-601. https://doi.org/10.1080/00014788.2015.1044495

Park, Y., Venkatachalam, M., \& Xiao, Y. (2018). Accounting Standards and Predictive Ability of Aggregate Accruals for Economic Growth. Duke University working paper. Retrieved on August 20, 2020, from: https://shidler.hawaii.edu/sites/shidler.hawaii.edu/files/about/youilchrispark_manuscript_vfinal_27aug2018.pdf

Patatoukas, P. N. (2020). Stock Market Returns and GDP News. Journal of Accounting, Auditing \& Finance. https://doi.org/10.1177/0148558X20913418

Pituch, K. A. \& Stevens, J. P. (2016). Applied Multivariate Statistics for the Social Sciences. Analysis with SAS and IBM's SPSS, $6^{\text {th }}$ edition. Toronto: Routledge.

Pop, M. A. (2018). Exploring the relationship between governance versus auditing and reporting standards. 2nd International Scientific Conference on Recent Advances in Information Technology, Tourism, Economics, Management and Agriculture - ITEMA 2018 - Graz, Austria. CONFERENCE PROCEEDINGS published by the Association of Economists and Managers of the Balkans, Belgrade, Serbia; 587-598. https://doi.org/10.31410/itema.2018.587

Rotariu, T., Badescu, G., Culic, I., Mezei, E., \& Muresan, C. (2006). Applied statistical methods in social sciences, Bucharest: Polirom.

Scott, W. R. (2015). Financial Accounting Theory, $7^{\text {th }}$ edition, Toronto: Pearson.

Sumiyana, S., Atmini, S., \& Sugiri, S. (2019). Predictive power of aggregate corporate earnings and their components for future GDP growth: An international comparison. Economics \& Sociology, 12(1), 125-142. doi:10.14254/2071-789X.2019/12-1/7

Sunder, S. (2016). Better financial reporting: Meanings and means. Journal of Accounting and Public Policy, 35 (3), 211-223.

Tiron-Tudor, A. \& Achim, A. M. (2019). Accounting quality and stock price informativeness: a cross-country study. Economic Research-Ekonomska Istraživanja, 32 (1), 2481-2499. Retrieved on June 10, 2020, from: https://www.tandfonline.com/doi/pdf/10.1080/1331677X.2019.1650655 